\title{
MIR197 wt Allele
}

National Cancer Institute

\section{Source}

National Cancer Institute. MIR197 wt Allele. NCI Thesaurus. Code C82151.

The human MIR197 wild-type allele is located in the vicinity of 1p13.3 and is approximately 74 bases in length. This allele, which encodes MIR197 pre-miRNA, plays a role in the regulation of gene expression. Alteration in the expression of this gene is associated with development of follicular thyroid carcinoma. 